\title{
REMARKABLE JOURNEY OF A LOST PORTRAIT
}

\author{
Irina Dean* \\ Museum World Magazine. \\ 105120, Moscow, str. Syromyatinskaya, house 5, building 3A, office 147.
}

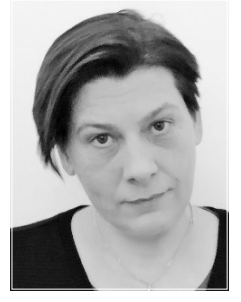

T ate last year for several weeks British media was following the story of a remarkable discovery made in a provincial South African town. A miniature portrait of a young Charles Dickens (1812-1870), lost for over 174 years, was found in a box of trinkets at a local auction. This unprecedented discovery is still talked about in the museum and art community capturing one's imagination by the unique nature of the find and the story behind it.

\section{The Find}

A local resident of Pietermaritzburg in the South African province of Kwazulu-Natal bought at a house clearance for an equivalent of approximately $\$ 30$ a tray of bric-a-brac. One of the items was a mouldy miniature picture in a frame. The owner sold the frame and due to the poor state of the painting he was going to throw the picture away. But curiosity took over and he decided to give it a go at cleaning the picture. As he was taking off the layers of mould and dirt, he started to realise that the artwork could have been of some importance. A face of a young and handsome Victorian gentleman with piercing eyes started appearing from under the dirt. After researching the image online the owner reached out for advice to Philip Mould \& Company, leading London dealer in British art and Old Masters. And soon the miniature portrait was on its way to England. Nobody could have guessed that it was on its way back home.

As the portrait arrived at Pall Mall Gallery it quickly became clear that this was, in fact, the lost portrait of Charles Dickens painted in 1843 and not seen in public since its inaugural presentation at the Royal Academy Summer Exhibition of 1844. Considered lost 30 years after its creation, it is an image only known to Dickens' biographers through an engraving, published in 1844. This thrilling emergence is not just because the portrait was lost for such a considerable amount of time, but also what it represents.

Philip Mould OBE, art dealer, broadcaster and renowned expert on British portraiture couldn't underestimate the significance of this find: "Every now and then something comes through our doors that alone justifies a career devoted to the research and representation of historical art. When the small package finally arrived at our gallery on a Monday morning in spring, it represented

* Dean Irina - Director of the Foreign Bureau of the Museum World Magazine. 105120, Moscow, str. Syromyatinskaya, house 5, building 3A, office 147 . 
just such a moment. Although covered with a particularly virulent species of South African mould, following its unwrapping Dickens' indomitable expression was still as affecting as it had been to the Victorian audience [...] It was an electrifying moment for us all."

\section{The Portrait - the author and the artist}

Today we know that young Dickens (he was only 31 at that time) had six or seven sittings for this portrait in 1843, between July and October at 1 Devonshire Terrace, London (Dickens' home between 1839 and 1851). The artist who painted the famous author of "Pickwick Papers" and "Nicholas Nickleby" was Margaret Gillies (1803-1887), a professional portrait miniature painter, and social activist. By that time, the artist and the author have known each other for many years through Margaret's partner (Gillies was deliberately unmarried) Dr. Thomas Southwood Smith (1788-1861), a pioneer in reforming sanitation. It is possible to imagine that Dickens and Gillies had a lot to discuss during the sittings as both the artist and the author were committed to social reform and championed the rights of the poor.

What is perhaps more exceptional is that Gillies was a professional female artist operating in highly influential circles at a time when it was almost impossible for a woman to earn an independent living for herself let alone the career. She and Dickens shared the common dedication to the plight of the poorest and most vulnerable in the society: he through his writing, and she - through her portraits and illustrations.

The discovery of this long lost portrait brings together so many strands of Dickens' history at a pivotal moment in his career. At that time his sales dropped, his recently published novel "Martin Chuzzlewit"(18421844) was a flop and the author found himself in debt. But Dickens wasn't giving up and invested heavily in his new creation - "A Christmas carol" (1843), probably the most popular piece of fiction that he ever wrote. The work was completed in astonishing 6 weeks and was done in parallel with the sittings for the portrait. It's an amazing coincidence that the portrait was discovered and brought into the public light in time for the 175th anniversary of the famous Christmas novel.

This portrait is also quite unique as it challenges our preconceptions about Dickens-the man and Dickens-the author. A lot of people possibly won't recognise this image as they are more used to seeing Dickens as a bearded Victorian gentleman on black-and-white photographs of the period. This is probably why the portrait remained unidentified for so long. This portrait shows Dickens young, handsome, clean-shaven, with an animated and intense gaze. The skill of the artist is evident in the finesse of every brushstroke, in each strand of hair and the sparkling eyes that look right into yours. Seeing this remarkable portrait only confirms the observation of one contemporary that "there is something about his eyes at all times that in women we call bewitching; in men we scarcely have any name for it... his complexion is extremely delicate... I should not blame him if he were somewhat vain of his hair."

But this portrait reveals much more about young Dickens than his appearance. In this portrait the artist skilfully united two faces of Dickens: the writer examining and reflecting on the ups and downs of his carrier and the impassioned campaigner for social reform. Poet Elizabeth Browning (1806-1861) captured the exact feeling that oozes from this portrait: "the dust and mud of humanity about him, notwithstanding those eagle eyes." Today, when you look at this portrait, it still feels like this, that arresting gaze reaches to you throughout centuries.

It's a fascinating combination of the artist and the subject, as these are two charismatic people each in its own way. One sees intimacy in this portrait as Dickens and Gillies knew each other for a long time and they shared a common passion for social reform, they both were deeply affected by the investigations and reports of child poverty, working conditions for women and children. So they had this common passion to use their skills, their talents, their position in society to make social changes. The portrait captures the essence of Dickens' personality, his vulnerability, his determination to make the 
difference. This wouldn't have been possible unless there was this meeting of minds between the artist and the sitter.

\section{The Portrait - the form and the purpose}

It is also interesting to understand what makes this portrait so special as a work of art. It is very interesting that Margaret Gillies chose the medium of a portrait miniature to make this portrait of Dickens because traditionally portrait miniatures are made for a very limited audience. Usually, they are painted for just three people: the artist, the person who commissioned the portrait and the person who received the portrait. Miniature portrait is intensely personal, intensely private and always taken from life, never taken from sketches. So Margaret Gillies made a type of portrait that is generally known to be a private image. She allowed herself into Dickens's private sphere in a way that no other artist was able to do. For example, according to the artist, Dickens' daughter Mary was present during the sittings, running in and out of the room while Dickens was trying to settle her on his knee.

The portrait was always destined for engraving prior to its public showing at the Royal Academy in 1844. It became a leading image in the book "A New Spirit of the Age" - a compilation of biographies of the brightest and best young writers of Victorian England, including Tennyson, Browning, and Mary Shelley. Ambitious aim of the book was to inspire and guide the new generation, to inspire people to do good. At the head of this tome was Dickens' biography and his portrait, engraved from Gillies miniature.

Margaret Gillies was ingenious in the use of the miniature format. Producing a private miniature and having it engraved for mass consumption! That was a clever move to produce "behind the scenes" image of the celebrity icon that any admirer would wish to see and possess. The engraving itself was and still is well known by Dickens enthusiasts, but the artist of the original unfortunately slipped into obscurity. Certainly, the discovery of the portrait shone new light on Gillies' role as a critical figure of social reform, pioneer of women's liberation and one of the first supporters of the suffrage movement. And now she can also be recast as one of the key figures in Dickens' early career, sharing the same views on the cruelty and amorality of Victorian society.

\section{The Provenance}

As you can imagine, it is highly unusual to find British works of art of such significance, out of all the places, in South Africa. When the portrait was discovered, nobody knew how it ended up in this part of the world. But after some investigation, the experts of Philip Mould and Company made a remarkable discovery that the journey of the miniature had a lot to do with the writer Mary Ann Evans, better known by her pin name - George Eliot (1819-1880). It's a connection that makes this discovery even more enriching and highlights the literary circles in which the artist moved. It is known that Eliot and her partner George Henry Lewes (1817-1878) were close friends with Charles Dickens, Margaret Gillies and her partner Dr. Thomas Southwood Smith. The research into this bohemian group of friends uncovered the reasons why the portrait was discovered on the other side of the world. It is almost certain that the miniature was gifted to one of George Lewes's three sons due to their close relationship with the artist and the author. In 1865 the eldest son Charles married the adopted daughter of Gillies and Southwood Smith. The other two brothers, intrepid explorers Thornton and Herbert travelled to the recently established British colony of Natal (today Kwazulu-Natal). Thornton left for South Africa in 1863 and his younger brother joined him three years later. Their close association with the prominent literary circles of London ensured their warm welcome in the educated high society of Durban and Pietermaritzburg. At that colonial time a lot of rich and powerful collected books and other objects of English culture. It is very probable that the portrait was sent out to Natal, as it was never mentioned in brothers' possessions during their journey to South Africa. It is more than likely that later it was sold or gifted to one of the prominent individuals who assisted brothers to settle in the new 
country. Even though the provenance of the lost portrait of Dickens might never be complete, the research provides a very good explanation as to how the miniature was found in the lowest point of the African continent. And above all, it tells a story of a remarkable journey from the heart of Victorian London, across the Atlantic Ocean, and back again.
Recently, after months of fundraising, Charles Dickens Museum in London acquired the portrait from Philip Mould \& Company. Now it will be presented to the public in a perfectly preserved corner of Victorian London - Dickens' study in his house at 48, Doughty street, London.

\section{Materials used:}

Philip Mould \& Company, "The Lost Portrait", exhibition at Philip Mould Gallery, London, UK, 22 November 2018 - 25 January 2019

Marizburg Sun. "Lost portrait of Dickens turns up in Pietermaritzburg", 23 November 2018

www.dickensmuseum.com, Charles Dickens Museum website, London. 